\title{
Tribute to the Pioneers of the International Committee of the Red Cross
}

\section{by Cornelio Sommaruga \\ President of the International Committee of the Red Cross}

At 60 'clock in the evening of 9 February 1863, in a place then called the "Casino", the members of the Geneva Public Welfare Society were assembled under the chairmanship of Gustave Moynier to discuss the publication of a popular edition of the French classics, the creation of a body of volunteer nurses attached to armies in the field (conclusion of Henry Dunant's book entitled "A Memory of Solferino") and the foundation of an agricultural camp for problem children!

At the time who would have imagined that such a day would become a historical landmark and the "true starting point of the Red Cross"- to quote Gustave Moynier himself? Who but a few well informed people would recall nowadays that this very ordinary meeting acquired such exceptional importance, because that was where five citizens of Geneva laid the foundations of the International Committee of the Red Cross and hence of the International Red Cross and Red Crescent Movement as a whole?

This is why the ICRC is particularly gratified to share in the commemoration of this major event, an initiative that we owe to the very active Henry Dunant Society together with the authorities of the Republic and Canton of Geneva and of the City of Geneva. To this tribute to the pioneers of the most universal humanitarian movement that exists, we shall now add a more lasting token in the form of a plaque which will bear witness to the history of humanitarian thinking, a modest and yet significant symbol of that altruistic and international spirit which has been and will continue to be the pride of our City of Geneva. 
The fact that the event we are celebrating took place in Geneva and that this city became the cradle of the Red Cross is hardly fortuitous. In the second half of the nineteenth century, Geneva was a prosperous city, open to the rest of Europe and above all the centre of international charity: numerous philanthropic societies there were engaged in a thousand and one forms of charitable activity. Among these societies, the Geneva Public Welfare Society played a particularly active part in helping abandoned children, detainees and the destitute. Geneva was the place where Jean-Henri Merle d'Aubigné preached the duty to assist the underprivileged; his appeal to the various communities to alleviate the suffering of victims of the conflicts that were ravaging the Europe of that time, particularly in Italy, found a wide audience and was largely followed. It was from Geneva also that Samaritans of all kinds went out to bring material and moral support to those in need, whatever their nationality or religion.

Even before Solferino, such was the "spirit of Geneva"-if you will pardon the expression-a spirit of generosity and altruism, already imbued with the principles of humanity, impartiality and neutrality; a spirit that gave their incentive to those whose memory we are commemorating here today.

Albeit such a spirit and the seed of the humanitarian message it contained had to be revealed to the world in order to achieve universal and lasting recognition. And so the humanitarian gesture accomplished by Henry Dunant at Solferino on 25 June 1859 was made known to the public of his time in "A Memory of Solferino". Inspired by a shattering experience, it was a work which shaped Henry Dunant's life and that of generations of Red Cross workers after him.

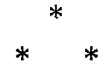

All of us are familiar with Henry Dunant the man, whose sensitive nature, foresight and force of persuasion pervade the book that so deeply impressed the European audience of his time. Dunant's ideas, however, still lacked precision and clarity. It took a man like Gustave Moynier, the chairman of the Geneva Public Welfare Society, to explain and translate Dunant's brilliant concept into clear and consistent terms. Such was the miracle that drew these two men together despite their considerable differences: Henry Dunant, the man who "imagined" the Red Cross, as Moynier himself acknowledged, the creative visionary with his unique gift of compassion for those who suffered, and his 


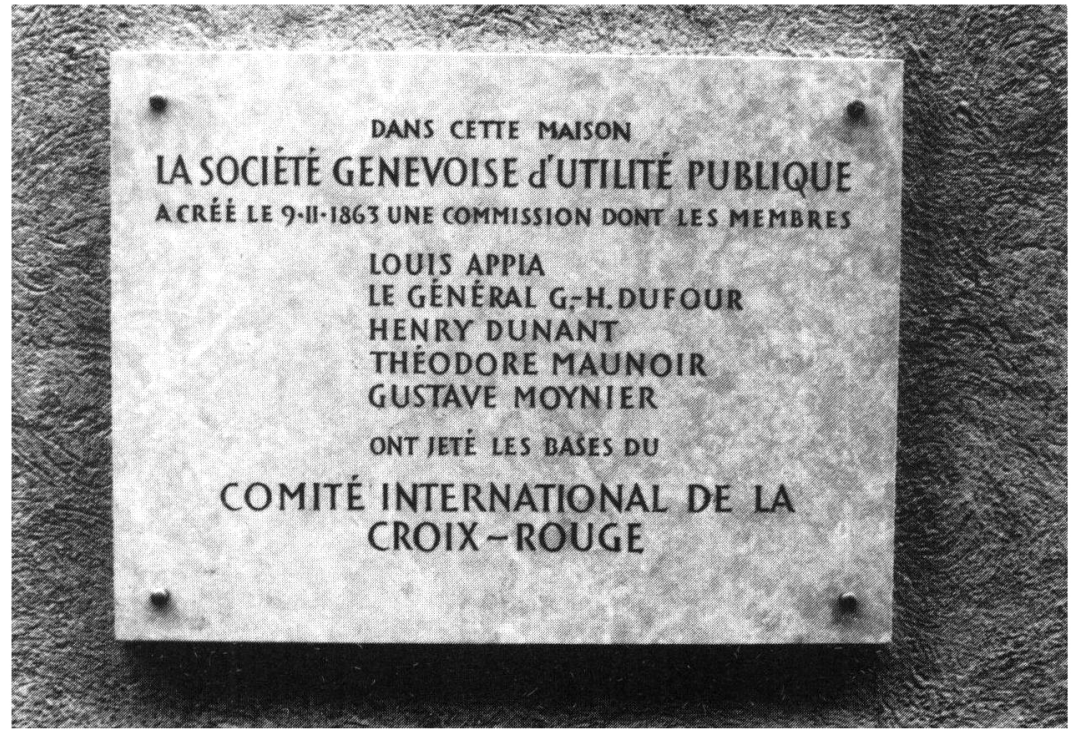

Unveiling of a commemorative plaque, on 9 February 1988, at the former Casino de Saint-Pierre, 3 rue de l'Evêché, Geneva.

(Photo: City of Geneva Monuments and Fountains Service) 


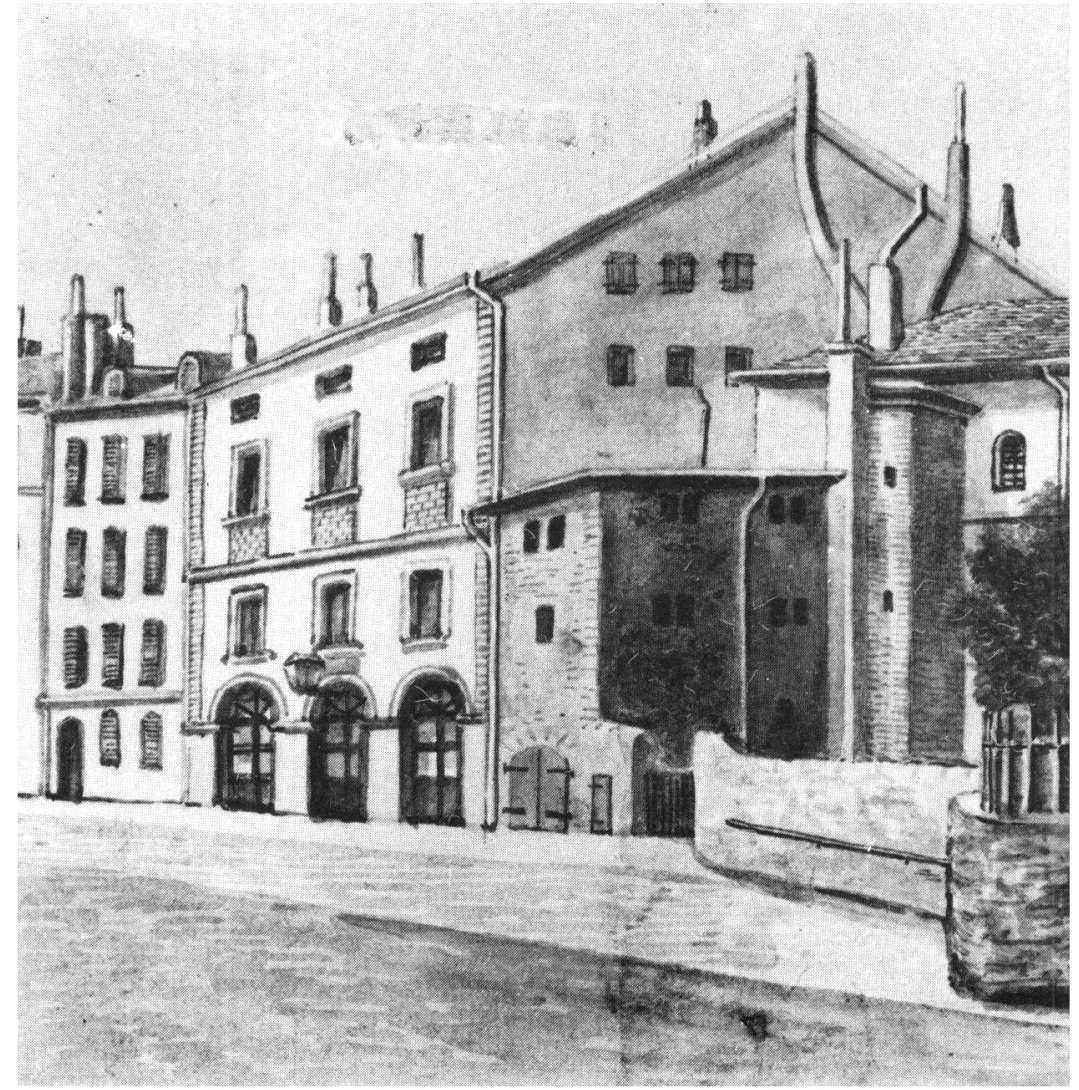

The former Casino (with its three arcades) at 3 rue de l'Evêché. On the ground floor were held the meetings of the Geneva Public Welfare Society which, on 9 February 1863, created the "Committee of Five".

(Philip Jamin (1848-1918) — drawing with watercolour (detail) Museum of Art and History, Old Geneva). 
capacity to comfort and give both material and moral support to those in need; and Gustave Moynier, the dialectitian, the organizer and theorist of social phenomena. In other words, their meeting was a conjunction of opposites - of the visionary and the rational, of the ardent enthusiast and the sober-minded sceptic. Far from negating each other, Dunant and Moynier joined efforts and gave substance and strength to the ideal they shared above all: to alleviate human suffering, to let their hearts be their guide and common sense prevail in the midst of violence and misery. To achieve this, Dunant and Moynier's answer was: try, try and try again.

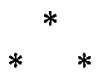

Time has shown that the association of these five men was perhaps not fortuitous either. They had so many things in common; not only the place where they met, but above all their faith.

More than a duty, charity was second nature to them. They all belonged to the same philanthropic and social circles. Dunant and Appia were both members of the Evangelical Society; Dunant, Dufour and Appia had met at the Geographical Society; Moynier, Dufour, Appia and Maunoir all four belonged to the Geneva Public Welfare Society. The five men had experience in common too: Dunant and Moynier, first of all, as we have already seen. Louis Appia, who showed a rapidly growing interest in war surgery, was to become the ambassador of Genevese charity in the hospitals of Piedmont and Lombardy; Dr. Maunoir, a man of considerable intelligence, was devoted to both his family and his patients, who all appreciated his patience, sollicitude and kindness. General Dufour's renown as a peace-maker grew as a result of the restraint and wisdom he showed in conducting the Sonderbund war.

This was indeed an extraordinary meeting of men who were all singularly ahead of their time: Henry Dunant, whose spontaneous act at Solferino foreshadowed the future work of the Red Cross and its guiding principles; Appia, who, at the time the battle of Solferino took place, was giving indiscriminate attention to the patients of Italian hospitals, and Dufour, whose orders to his officers in 1847 prefigured certain fundamental provisions of the Geneva Conventions.

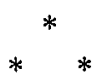


In fact, it was not merely a matter of creating a body of volunteer nurses. Dunant's thinking went much, much further: he urged States to adopt "some international principle, sanctioned by a Convention inviolate in character, which, once agreed upon and ratified, might constitute the basis for societies for the relief of the wounded in the different European countries."

Starting on 17 February 1863, this tremendous task was accomplished by the Committee of Five on 22 August 1864, when the first Geneva Convention was signed. It required considerable determination, tenacity, imagination, audacity and intense activity, according to Dunant's account.

Maybe it also needed that slight touch of madness that one finds in all true idealists, whose fantasy inspires them to achieve great things.

What the five men needed above all was to overcome their feelings of uncertainty. That same evening of 9 February, General Dufour, being the realistic soldier he was, was not sure whether this great venture would succeed, and Gustave Moynier was not by any means convinced that the Berlin Conference was the best place to start spreading Dunant's ideas. Moynier again-on the eve of the Conference in October 1863-admitted in confidence that the members of the Committee felt "so small and so weak in the face of the monumental task that lay before them"; Moynier also doubted whether the government delegations would agree to the neutrality of medical personnel; this was an idea put forward by Dunant in Berlin, without consulting his colleagues.

This other inspired idea of Dunant's that all medical staff should be recognized and treated as neutral-an idea which was shared by Dr. J. Basting, a Dutch army medical officer-was later adopted by the other members of the Committee.

We must not forget that at the time the concept of neutrality was still unheard of; it was customary to consider doctors and nurses as ordinary combatants, and it was by no means easy for Dunant to win his friends over to this fundamental concept. But ironically enough for history in the making, the 1863 Conference more readily accepted neutrality than the creation of a body of volunteer nurses!

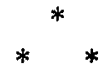


In putting up this plaque, we wished to pay tribute to these five men, who had no other means available to them than their profound motivation, imagination and audacity and who deliberately induced a change in the course of history by laying down the foundations of a universal movement, which today is more alive and indispensable than ever.

In remembering that this small Committee of Five, which in its original form was destined to be but temporary, the ICRC which I represent can be proud of the task it has been accomplishing for the past 125 years on behalf of all who suffer. The ICRC is better able to appreciate the responsibilities entrusted to it and which require it-nowadays more than ever - to remain unconditionally faithful to those simple precepts laid down by Dunant, Appia, Dufour, Maunoir and Moynier: to alleviate, and insofar as possible, to eliminate human suffering; to ensure that all individual human beings are respected, not because they are citizens of a given State, but simply because they are human beings; to identify completely with those who suffer; and to know the limits of humanitarian action, which is the fundamental guarantee of the unity and universality of the Red Cross. 